\title{
Constitutively Active Akt Induces Enhanced Myelination in the CNS
}

\author{
Ana I. Flores, ${ }^{1 \star}$ S. Priyadarshini Narayanan, ${ }^{1 *}$ Emily N. Morse, ${ }^{1}$ H. Elizabeth Shick, ${ }^{1}$ Xinghua Yin, ${ }^{1}$ Grahame Kidd, ${ }^{1}$ \\ Robin L. Avila, ${ }^{2}$ Daniel A. Kirschner, ${ }^{2}$ and Wendy B. Macklin ${ }^{1}$ \\ ${ }^{1}$ Department of Neurosciences, Cleveland Clinic, Cleveland, Ohio 44195, and 2Department of Biology, Boston College, Chestnut Hill, Massachusetts 02467
}

The serine/threonine kinase Akt regulates multiple cellular functions. The current studies identify a new role for Akt in CNS myelination. In earlier studies on cultured oligodendrocytes, we showed that neuregulin signals through phosphatidylinositol-3'-0H kinase and Akt to enhance survival of oligodendrocytes. However, when transgenic animals were generated that overexpressed constitutively active Akt in oligodendrocytes and their progenitor cells, no enhanced survival of oligodendrocytes or progenitors was found. No alteration in the proliferation or death of progenitors was noted. In contrast, the major impact of Akt overexpression in oligodendrocytes was enhanced myelination. Most interestingly, oligodendrocytes in these mice continued actively myelinating throughout life. Thus, expression of constitutively active Akt in oligodendrocytes and their progenitor cells generated no more oligodendrocytes, but dramatically more myelin. The increased myelination continued as these mice aged, resulting in enlarged optic nerves and white matter areas. In older animals with enlarged white matter areas, the density of oligodendrocytes was reduced, but because of the increased area, the total number of oligodendrocytes remained comparable with wild-type controls. Interestingly, in these animals, overexpression of Akt in Schwann cells did not impact myelination. Thus, in vivo, constitutively active Akt enhances CNS myelination but not PNS myelination and has no impact developmentally on oligodendrocyte number. Understanding the unique aspects of Akt signal transduction in oligodendrocytes that lead to myelination rather than uncontrolled proliferation of oligodendrocyte progenitor cells may have important implications for understanding remyelination in the adult nervous system.

Key words: Akt; phosphatidylinositol-3'-OH kinase; oligodendrocyte; myelin; Schwann cell; transgenic

\section{Introduction}

Vertebrate myelination is a complex process involving reciprocal interactions between neurons and glia, which is essential for rapid, saltatory conduction of action potentials along axons. Pathological conditions such as multiple sclerosis lead to oligodendrocyte loss and CNS demyelination (for review, see Frohman et al., 2006). Thus, identifying pathways/molecules involved in oligodendrocyte survival and differentiation would enhance therapeutic approaches toward remyelination. In earlier studies, we demonstrated that the phosphatidylinositol-3' $-\mathrm{OH}$ kinase (PI3 kinase)/Akt pathway is crucial for the survival of oligodendrocyte progenitor cells in vitro (Flores et al., 2000). We therefore began to investigate the effect of Akt in oligodendrocytes in vivo. This experiment was intended to address whether constitutively active Akt could increase the number of oligodendrocytes in vivo, or reduce oligodendrocyte loss in adult pathol-

Received Feb. 12, 2007; revised March 31, 2008; accepted May 5, 2008.

This work was supported by a grant (W.B.M.) and a fellowship (A.I.F.) from the National Multiple Sclerosis Society, and by institutional support from Boston College (D.A.K.). We thank Kelley Weinfurtner and Feng Wang for help on this manuscript.

${ }^{*}$ A.I.F. and S.P.N. contributed equally to this work.

Correspondence should be addressed to Wendy B. Macklin, Department of Neurosciences, NC30, Cleveland Clinic, 9500 Euclid Avenue, Cleveland, 0H 44195. E-mail: mackliw@ccf.org.

A. I. Flores' present address: Hospital 12 0ctubre, Unidad de Investigación, Avenida Córdoba s/n, 28041 Madrid, Spain.

DOI:10.1523/JNEUROSCI.0150-08.2008

Copyright $\odot 2008$ Society for Neuroscience $\quad$ 0270-6474/08/287174-10\$15.00/0 ogies. Transgenic mice were generated using the mouse myelin proteolipid protein $(P l p)$ promoter, which we have shown is expressed throughout the oligodendrocyte lineage (Wight et al., 1993; Fuss et al., 2000; Mallon et al., 2002).

In the transgenic mice described here, the $P l p$ promoter drives expression of constitutively active Akt1. This form of constitutively active Akt has aspartic acids at $\mathrm{Thr}^{308}$ and $\operatorname{Ser}^{473}$ (Akt-DD), which are the two sites whose phosphorylation leads to full activation of Akt (Bellacosa et al., 1991). It has been overexpressed in mammary epithelium in transgenic mice, in which it induces hyperplasia. Thus, its expression provides a major cell survival signal, but does not in itself induce tumors (Hutchinson et al., 2001).

Strikingly, the current studies identify novel, unexpected regulation of CNS myelination by Akt. Thus, although Akt may regulate some aspects of oligodendrocyte progenitor survival, its overexpression does not impact progenitor cell number or proliferation. Its more dramatic impact in oligodendrocytes in vivo is in enhancing oligodendrocyte maturation, and in particular the amount of myelin produced. Oligodendrocytes in these transgenic mice started myelinating earlier, and produced more myelin than wild-type (WT) mice. Most interestingly, they appeared to continue active myelination into adulthood. Thus, expression of Akt-DD in oligodendrocytes and their progenitor cells generated normal numbers of oligodendrocytes, but dramatically increased the amount of myelin produced, and sustained active 
myelination throughout adulthood. Understanding the unique aspects of Akt signal transduction in oligodendrocytes that lead to myelination rather than uncontrolled proliferation of oligodendrocyte progenitor cells is highly relevant to understanding remyelination in the adult nervous system.

\section{Materials and Methods}

Materials. Antibodies were obtained from Cell Signaling Technology (Akt1); Aves Labs (P0); Sigma (actin); Millipore Bioscience Research Reagents [myelin basic protein (MBP)]; Roche [bromodeoxyuridine (BrdU)]; and Santa Cruz Biotechnology [platelet-derived growth factor receptor $\alpha(\operatorname{PDGFR} \alpha)$ ]; and the AA3 clone was obtained from Dr. Steve Pfeiffer (University of Connecticut, Farmington, CT).

Production of Plp-Akt-DD mice. Transgenic mice expressing constitutively active Akt (HAAkt308D473D, Akt-DD; a kind gift from James R. Woodgett, Ontario Cancer Institute, Toronto, Canada) driven by the Plp promoter (Wight et al., 1993) were generated. The Akt cDNA was inserted into the AscI/PacI sites of the modified Plp promoter cassette (Fuss et al., 2000), and the Plp promoter/Akt-DD insert was injected to generate transgenics in SJL/SWR F1 mice. Positive founders were identified by PCR amplification of tail DNA using IntronSV40F (5'-GCAGTGGACCACGGTCAT-3') and Akt lower (5'-CTGGCAACTAGAAGGCACAG-3') primer sequences. Analyses were done from littermatched mice in all developmental experiments, and where possible with older animals. Studies were initially done on all three lines, which overexpressed Akt at similar levels. Akt was expressed in oligodendrocytes in all three Plp-Akt-DD lines, and overexpression of myelin proteins in the CNS was noted in all three lines. The Plp-Akt-DD3 line died out before extensive further analysis, but both $P l p$-Akt-DD5 and Plp-Akt-DD9 had similar phenotypes. For simplicity, Plp-Akt-DD9 was used for the extensive analyses shown here, with comparative data for Plp-Akt-DD3 or Plp-Akt-DD5 in specific experiments in supplemental material (available at www.jneurosci.org).

Western blot analysis. Mouse cerebrum lysates were prepared in $50 \mathrm{~mm}$ Tris/0.3 M sucrose, $\mathrm{pH} 7.6$, containing protease inhibitor mixture (Roche Applied Science). After SDS-PAGE (8-16\%, Tris-Gly), proteins were transferred onto polyvinylidene fluoride membrane and blocked with $5 \%$ milk (1 h) or, for P0 immunoblots, onto nitrocellulose. Subsequently, blots were incubated with primary antibodies (Akt1, 1:1000; AA3, 1:1000; MBP, 1:2000; P0, 1:500; and $\beta$-actin, 1:10,000) overnight at $4^{\circ} \mathrm{C}$, and visualized using enhanced chemiluminescence (ECL-Plus; GE Healthcare).

Akt activity assay. Akt activity was assayed using a nonradioactive Akt kinase assay kit (Cell Signaling Technology).

Immunohistochemistry. Mice were perfused with saline followed by $4 \%$ paraformaldehyde in PBS, after which brains were dissected, postfixed overnight at $4^{\circ} \mathrm{C}$, and cryoprotected. Free-floating coronal sections (30 $\mu \mathrm{m})$ were cut and treated as described previously (Trapp et al., 1997). Sections were incubated overnight at $4^{\circ} \mathrm{C}$ in primary antibodies (Akt, 1:500; AA3, 1:3000; MBP, 1:2000; and PDGFR $\alpha$, 1:500 in 3\% normal goat serum), and analyzed as described previously (Trapp et al., 1997).

Cell proliferation assay. Animals at postnatal day 5 were injected with $\mathrm{BrdU}(100 \mu \mathrm{g} / \mathrm{g}$ of body weight $)$ in PBS, three times at $4 \mathrm{~h}$ intervals. Mice were perfused at $24 \mathrm{~h}$ after the first injection. Tissue sections were analyzed for proliferating cells by BrdU detection using anti-BrdU antibody (GE Healthcare) following the manufacturer's protocol.

Cell death assay. Terminal deoxynucleotidyl transferase-mediated biotinylated UTP nick end labeling (TUNEL) assay was performed using the In Situ Cell Death Detection Kit (Roche), according to the manufacturer's protocol.

RNA extraction and quantitative real-time PCR. Total RNA from WT and Plp-Akt-DD cerebrum tissue was isolated using TRIzol reagent (Invitrogen). cDNA was generated from $1-3 \mu \mathrm{g}$ of total RNA by Retrotranscriptase II (Invitrogen) and the transcripts were detected and amplified by quantitative real-time PCR in a LightCycler machine (Roche) following the manufacturer's instructions. Glyceraldehyde 3-phosphatase dehydrogenase (GAPDH) was used as internal control. Real-time PCR conditions were as follows: denaturation: $95^{\circ} \mathrm{C}, 30 \mathrm{~s}, 1$ cycle; annealing and amplification: $59^{\circ} \mathrm{C}, 5 \mathrm{~s} ; 72^{\circ} \mathrm{C}, 20 \mathrm{~s}$ respectively, 40 cycles; dissociation/ melting curve: $65^{\circ} \mathrm{C}, 15 \mathrm{~s}, 1$ cycle. All primers used were from Sigma-Genosys.

Quantification of oligodendrocytes. Plp-Akt-DD mice were bred to WT Plp-EGFP mice, and the number of green oligodendrocytes was quantified, comparing littermate $P l p$-Akt-DD and WT mice. For quantification of samples from postnatal day 14 (P14) to P30, vibratome sections (20 $\mu \mathrm{m})$ were obtained, and images were taken for one slide from each of three mice per genotype. For each slide, multiple images were taken using a $20 \times$ objective on a Leica DMR microscope with an Optronics Magnafire digital camera, which were overlapped and combined to generate a master image. The total number of oligodendrocytes was quantified in the area outlined in Figure $3 E$ for each slide. The area quantified encompassed oligodendrocytes in the corpus callosum, cingulate cortex, primary and secondary motor cortex, and part of the primary somatosensory cortex.

A modification of the methods of Coggeshall (1992) was used for quantifying green oligodendrocytes at older ages. This was essential because of the enlargement of white matter areas in older $P l p$-Akt-DD mice. Confocal images of corpus callosum (near the midline) were collected on a Leica SP5 confocal microscope at $0.5 \mu \mathrm{m}$ steps using a $40 \times 1.25 \mathrm{nu}-$ merical aperture oil-immersion lens from $30 \mu \mathrm{m}$ tissue slices. Image file stacks were opened in ImageJ software (http://rsb.info.nih.gov/ij/ index.html), and the center of each cellular nucleus was located by stepping up and down in the $z$-series. A colored dot was placed at the center of each nucleus. The top slice was discarded, and dots in cells touching the left and upper margins were removed to avoid double counting cells partially in the field. The dots were counted and results expressed as nuclei per cubic millimeter. All measurements were made in ImageJ or Adobe Photoshop. The area of the corpus callosum was measured on confocal images taken with a $2.5 \times$ lens.

Electron microscopy. Mice were perfused with $4 \%$ paraformaldehyde/ $2.5 \%$ glutaraldehyde in 0.08 м Sorenson's buffer. Optic nerves and ventral roots were washed in $0.08 \mathrm{~m}$ Sorenson's buffer and postfixed in $1 \%$ osmium tetroxide, dehydrated in graded ethanol series, and embedded in Epon. Epon sections were analyzed $(1 \mu \mathrm{m})$, and then ultrathin sections $(85 \mathrm{~nm})$ were cut and stained with uranyl acetate and lead citrate. Electron micrographs were taken using Philips 201 TEM at $60 \mathrm{kV}$ or Philips CM100 TEM at $80 \mathrm{kV}$.

Calculation of $\mathrm{g}$ ratio and axon diameter. Diameters of axons and the corresponding myelinated fibers were calculated from their areas, derived using Scion Image. Only relatively circular, well fixed and well defined axons were used for measurement. At least 100 randomly selected axons were analyzed per animal, with three animals per genotype.

$X$-ray diffraction of optic and sciatic nerves. To assess feasibility of distinguishing structural differences between $P l p$-Akt-DD and WT nerves using $\mathrm{x}$-ray diffraction, we first recorded diffraction patterns from glutaraldehyde-fixed optic nerves at 2 months of age. Because these preliminary measurements showed a structural difference between the two, we proceeded to analyze optic nerves and sciatic nerves from unfixed tissue at 2 and 6 months of age. Mice were killed by decapitation. Dissected nerves were tied off at their ends, maintained in physiological saline (154 mm NaCl, $5 \mathrm{~mm}$ Tris buffer, $\mathrm{pH}$ 7.4) and sealed in quartz capillary tubes. X-ray diffraction spectra were recorded from unfixed nerves (Avila et al., 2005), using nickel-filtered, single-mirror focused $\mathrm{CuK} \alpha$ radiation from a fine-line source on a $3.0 \mathrm{~kW}$ Rigaku x-ray generator that was outfitted with a linear, position-sensitive detector (Molecular Metrology). Detector characteristics and specimen-to-film distance were established as described previously (Avila et al., 2005). Myelin periodicity was calculated from the positions of the reflections in the patterns. The relative amount of multilamellar myelin was determined by measuring the total integrated intensity $(M)$ above "background" $(B)$. The fraction of scattered intensity that is attributable to myelin is $M /(M$ $+B$ ) (Avila et al., 2005). The disorder in the stacking of membranes in multilamellar myelin was determined by plotting the integral widths $w^{2}$ as a function of $h^{4}$, where the intercept on the ordinate axis is inversely related to the number of repeating units and the slope is proportional to the fluctuation in period (stacking disorder) (Inouye et al., 1989). 
Statistical analysis. Statistical significance was determined by paired $t$ test analysis.

\section{Results}

Constitutively active Akt is overexpressed in

Plp-Akt-DD oligodendrocytes

In Plp-Akt-DD mice, Akt was overexpressed from early ages, even at P10 (Fig. $1 A$ ), with increasing amounts as the animals matured, and its expression was significantly enriched in oligodendrocytes (Fig. $1 B$; supplemental Figs. $1 A, 2 A$, available at www. jneurosci.org as supplemental material). Baseline Akt expression was noted in WT mice, but it was primarily expressed at low levels in neurons, which was not obvious in these images. Three lines of transgenic mice were analyzed, with data from $P l p$-Akt-DD9 presented in Figures 1-7 and data from Plp-Akt-DD3 and Plp-AktDD5 presented in supplemental figures (available at www. jneurosci.org as supplemental material). These analyses demonstrated overexpression of the protein in Plp-Akt-DD mice primarily in oligodendrocytes, and assay of the tissue for Akt activity indicated that there was increased Akt activity in wholebrain homogenates of young and adult Plp-Akt-DD mice (Fig. 1C).

\section{Expression of constitutively active Akt in oligodendrocytes and their progenitors did not alter the number or proliferation of oligodendrocyte progenitor cells}

It is known that the Plp promoter is expressed in oligodendrocyte progenitor cells, because $P l p$-promoter-driven EGFP is expressed in NG2-positive, PDGFR $\alpha$-positive oligodendrocyte progenitors [for extensive analysis of Plp promoter expression in oligodendrocyte progenitor cells, see Mallon et al. (2002)]. Thus, it was anticipated that Akt would be overexpressed in oligodendrocyte progenitor cells in Plp-Akt-DD mice. Given the known control of Akt in cell survival, it was important to assess the impact of overexpression of constitutively active Akt in oligodendrocyte progenitor cells. To quantify oligodendrocyte progenitor cell number, $P l p$-Akt-DD mice were therefore crossed with $P l p$-EGFP mice (Mallon et al., 2002). At P6 in the cortex, the only PlpEGFP-positive cells are oligodendrocyte progenitor cells (Mallon et al., 2002). In Plp-Akt-DD/Plp-EGFP mice, both EGFP and Akt were expressed at low levels in oligodendrocyte progenitor cells in cortical cells at P6 (Fig. 2A). In this image, clearly double-labeled oligodendrocyte progenitor cells are noted with arrows, and these are the cells that express higher levels of EGFP. However, at high contrast, essentially all EGFP-positive oligodendrocyte progenitor cells in this image expressed some Akt (data not shown). Proliferation of PDGFR $\alpha$-expressing oligodendrocyte progenitor cells was determined by BrdU injection (Fig. $2 B$ ). The total number of PDGFR $\alpha$-positive cells and of $\operatorname{BrdU/PDGFR} \alpha$-double positive cells was quantified in three regions within the cingulate and motor cortex in P6 mice (Fig. 2C). No differences were found for the number of oligodendrocyte progenitor cells or the number of proliferating progenitor cells (Fig. 2D). To assess whether oligodendrocyte progenitor cell survival was altered in these mice, TUNEL assays were conducted. No difference in the number of TUNEL-positive cells was found between WT $(9.4 \pm 1.6$ cells/hemisphere) and Plp-Akt-DD $(9.3 \pm 2.4$ cells/hemisphere $)$ samples.

Early and enhanced myelination occurred in Plp-Akt-DD, but no increase in oligodendrocyte numbers

Although there was no change in the number or proliferation of oligodendrocyte progenitor cells, there was increased expression
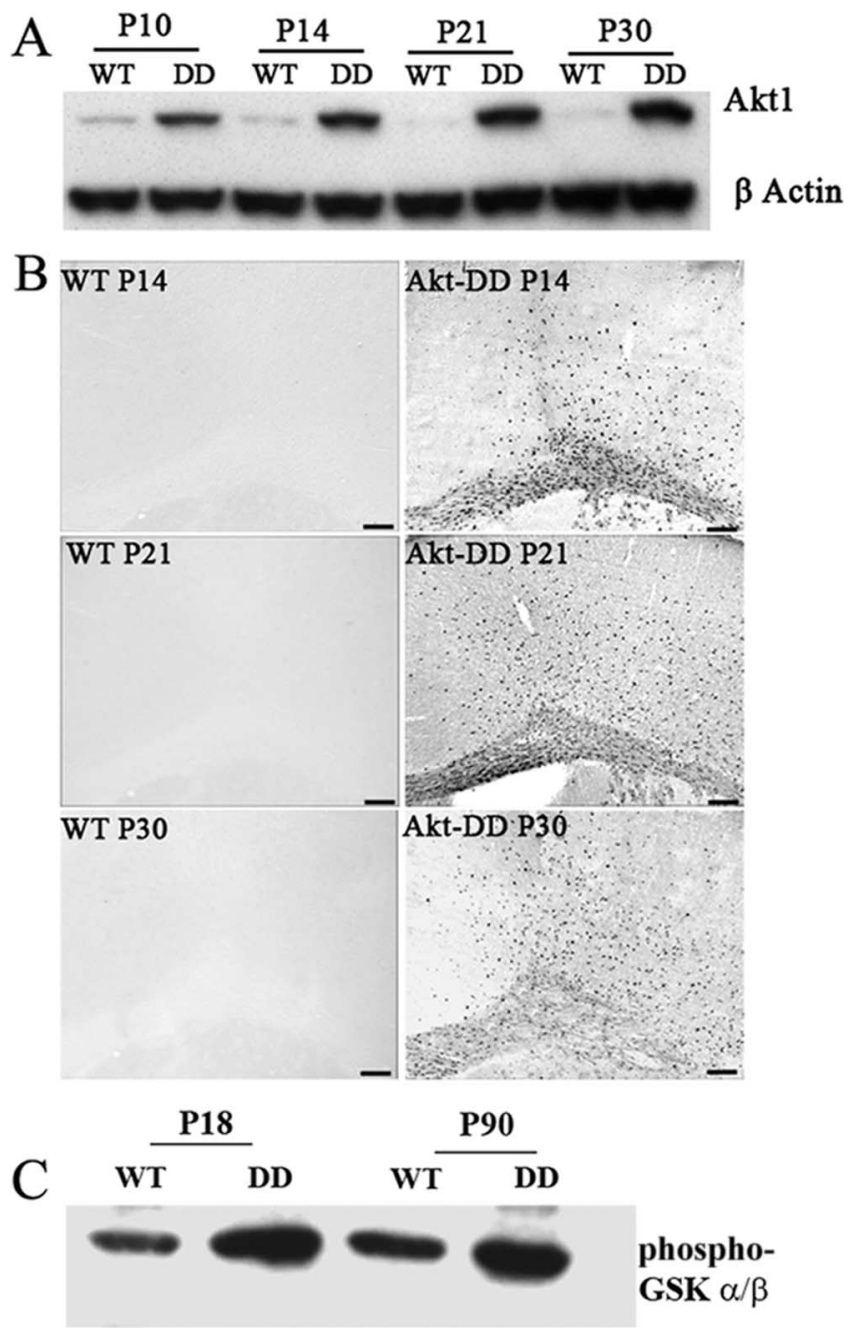

Figure 1. Active Akt is overexpressed in oligodendrocytes in P/p-Akt-DD mice. A, Cerebrum samples from littermate WT and Plp-Akt-DD9 mice were analyzed for Akt expression by Western blot at P10, P14, P21, and P30, and a representative blot is presented. The number of pairs of animals analyzed at each age varied from 5 to $21 . \boldsymbol{B}$, Akt was overexpressed in oligodendrocytes of Plp-Akt-DD9 mice (DD) as shown by representative immunostained sections for Akt at P14, $\mathrm{P} 21$, and P30. The number of pairs of animals analyzed at each age varied from 6 to 32 . Scale bars, $200 \mu \mathrm{m}$. C, Akt kinase assay (using GSK-3 as substrate) was used to confirm that the overexpressed Akt was active.

of PLP, DM20 (Fig. 3A,B), and the MBPs (data not shown) in Plp-Akt-DD9 mice as early as P10. (For analysis of Plp-Akt-DD3 and DD5, see supplemental Figs. 1, 2, available at www. jneurosci.org as supplemental material.) This increased gene expression was quantified for PLP, myelin oligodendrocyte glycoprotein (MOG), and MBP mRNA by real-time PCR (Fig. 3C). The differential of $\mathrm{Plp}$-Akt-DD myelination to WT myelination increased with development. Differences at P10 were minimal, but by P21 both at the protein and mRNA level, there was dramatically increased expression of myelin genes. These differences remained high between $\mathrm{P} 21$ and $\mathrm{P} 30$, which is the peak of active myelination during brain development.

To quantify oligodendrocyte number, $P l p$-Akt-DD mice were crossed with Plp-EGFP mice (Mallon et al., 2002). Akt overexpression was still seen in oligodendrocytes in these doubletransgenic mice, as well as the increase in myelination (at P30, data not shown). Unexpectedly, when oligodendrocytes were quantified in $\mathrm{Pl}$-EGFP/Plp-Akt-DD mice, no increase in the number of oligodendrocytes was found relative to WT Plp-EGFP 

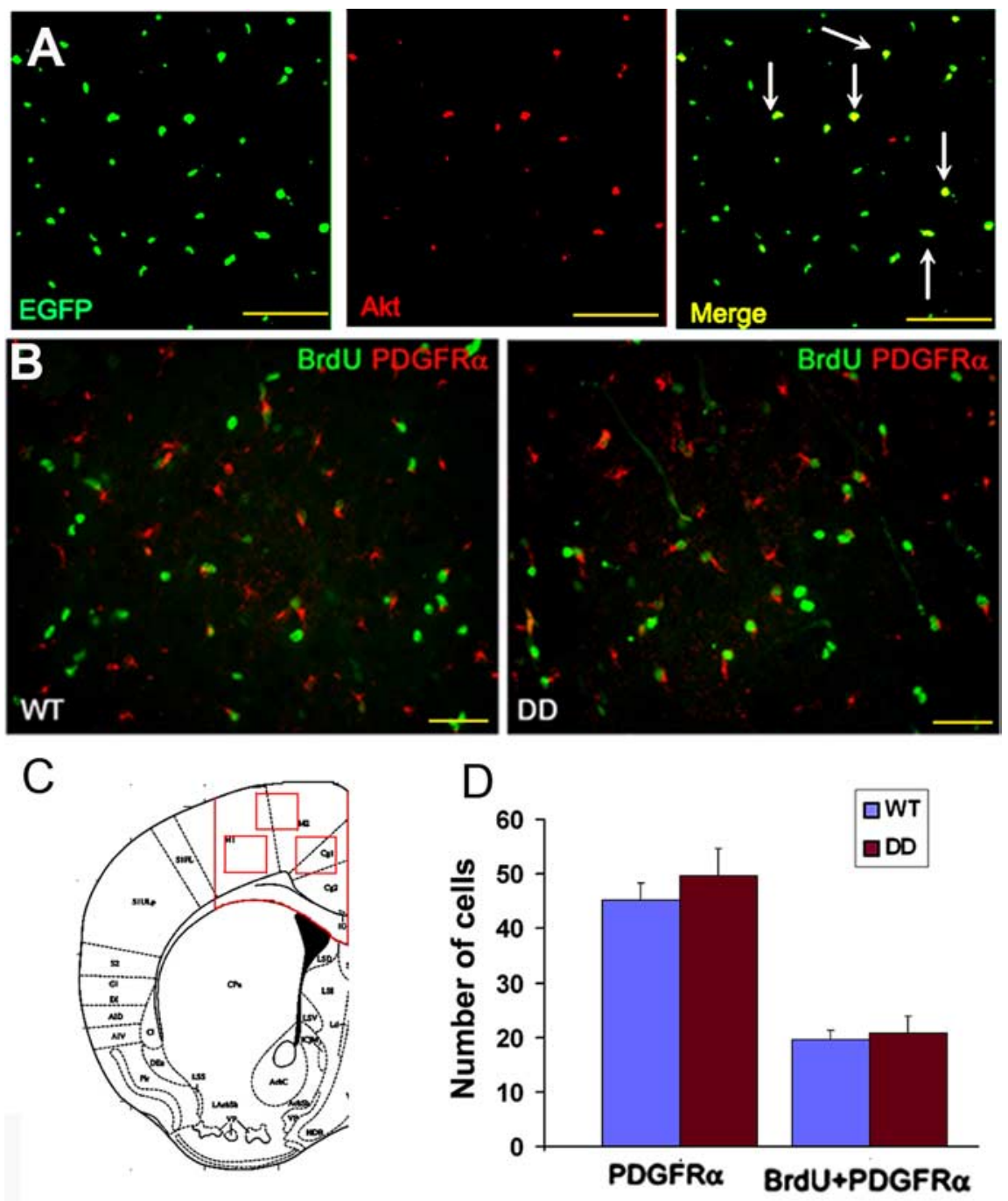

Figure 2. Oligodendrocyte progenitor cell number, proliferation, and survival are unaffected in PIp-Akt-DD mice. A, PIp-AktDD9/PIp-EGFP littermate cerebrum samples were analyzed at P6 for expression of Akt. Akt overexpression was observed only in EGFP-positive cells (arrows) in these samples, which, as shown by Mallon et al. (2002), are oligodendrocyte progenitors. $n=4$. B, PIp-Akt-DD9 and WT littermates were injected with BrdU on P5 and analyzed on P6 for PDGFR $\alpha$-positive or BrdU/PDGFR $\alpha$ positive cells. $n=3$. C, The three areas in motor cortex (M1, primary motor cortex; M2, secondary motor cortex) and cingulate cortex ( $\mathrm{Cg} 1$, cingulate cortex area 1; $\mathrm{Cg} 2$, cingulate cortex area 2) that were studied to quantify progenitors undergoing cell proliferation are boxed [Franklin and Paxinos (2008), their Fig. 24, modified with permission]. D, The number of PDGFR $\alpha$ cells and the number of BrdU-positive PDGFR $\alpha$ cells were quantified in cortical areas as shown in $\boldsymbol{C}$. The total number of cells for the three combined areas was obtained from one slide each from three animals per genotype. The average of the three samples per genotype is presented. There was no difference in either the number of progenitors or the number of proliferating cells. Scale bars: $\boldsymbol{A}, 25 \mu \mathrm{m} ; \boldsymbol{B}, 50 \mu \mathrm{m}$. Error bars represent SEM.

mice (Fig. 3D-F). The total number of green oligodendrocytes (Fig. $3 F$ ) was quantified in the region in the motor and cingulate cortex outlined in Figure 3E. Thus, overexpression of constitutively active Akt in oligodendrocytes did not increase the number of oligodendrocytes in developing or young adult mice.

Because there was no increase in the number of oligodendrocytes in $\mathrm{Plp}$-Akt-DD mice, it was likely that there was an increase in the amount of myelin per oligodendrocyte. This was studied in optic nerve, which was increased in size in Plp-Akt-DD mice (Fig. 4A). The increase in myelin was demonstrated by electron microscopy (Fig. $3 B$ ), where the $g$ ratio for myelin was quantified, i.e., the ratio of the diameter of the myelinated fiber to the diameter of the corresponding axon. The $g$ ratio for myelin in 2-month-old Plp-Akt-DD mice was $0.574 \pm 0.010$, compared with $0.672 \pm 0.009$ in WT $(p<$
$0.001 ; n=3)$. Thus, expression of constitutively active Akt in oligodendrocytes increased the amount of myelin generated per cell, producing thicker myelin sheaths. However, the average axonal diameter was unchanged $(0.698 \pm 0.021$ $\mu \mathrm{m}$ in $\mathrm{Plp}$-Akt-DD mice compared with $0.689 \pm 0.057 \mu \mathrm{m}$ in WT; $n=3)$. Scatter diagrams of the distribution of the $g$ ratio as a function of axon diameter indicated a tight distribution of WT myelinated axons with a $g$ ratio between 0.5 and 0.8 , whereas the distribution was much broader for $P l p$-Akt-DD mice, both in the range of $g$ ratios and the diameter of myelinated axons, with a slight increase in the number of very small and very large myelinated axons (Fig. 4C).

Enhanced myelination continued as $P l p$ Akt-DD mice age

Strikingly, active CNS myelination continued as the Plp-Akt-DD mice aged. At all ages, $P l p$-Akt-DD mice had more PLP/ DM20 protein than WT. At 3 months of age, $P l p$-Akt-DD mice had more PLP and DM20 expression than WT mice at 6 months of age (Fig. $5 A$; for data on $P l p$ Akt-DD5, see supplemental Fig. 3, available at www.jneurosci.org as supplemental material). Plp-Akt-DD mice continued accumulating myelin proteins up to at least 10 months of age. Interestingly, WT samples also continued to accumulate myelin protein as animals aged. This unexpected observation is consistent with studies showing increases in myelination as rats and monkeys age $(\mathrm{Pe}$ ters et al., 2001; Yates and Juraska, 2007). Myelin mRNAs were increased as well in Plp-Akt-DD mice relative to $\mathrm{WT}$, with WT mRNA concentrations staying essentially stable between 2 and 8 months of age, whereas PLP, myelin-associated glycoprotein (MAG), MBP, and MOG mRNAs continued to increase in $\mathrm{Plp}$ Akt-DD mice with age (Fig. 5B). These increases in myelin mRNAs and proteins resulted in an increase in the amount of white matter in $\mathrm{Plp}$ Akt-DD mice. The corpus callosum in 5-month-old PlpAkt-DD mice was larger than in WT mice (Fig. $5 C$, arrows). This increase was also observed in other white matter areas, with an enlarged brainstem and anterior commissure (supplemental Fig. 3, available at www.jneurosci.org as supplemental material). The actual brain weight did not change in early adult animals, but from 5 months of age on, the brain weight of Plp-Akt-DD mice was statistically higher than WT (supplemental Fig. 4, available at www.jneurosci.org as supplemental material) This continued myelination may become pathologic, because these mice did not survive past 14 months of age. Thus, Akt overexpression in oligodendrocytes led to active myelination, possibly indefinitely. 


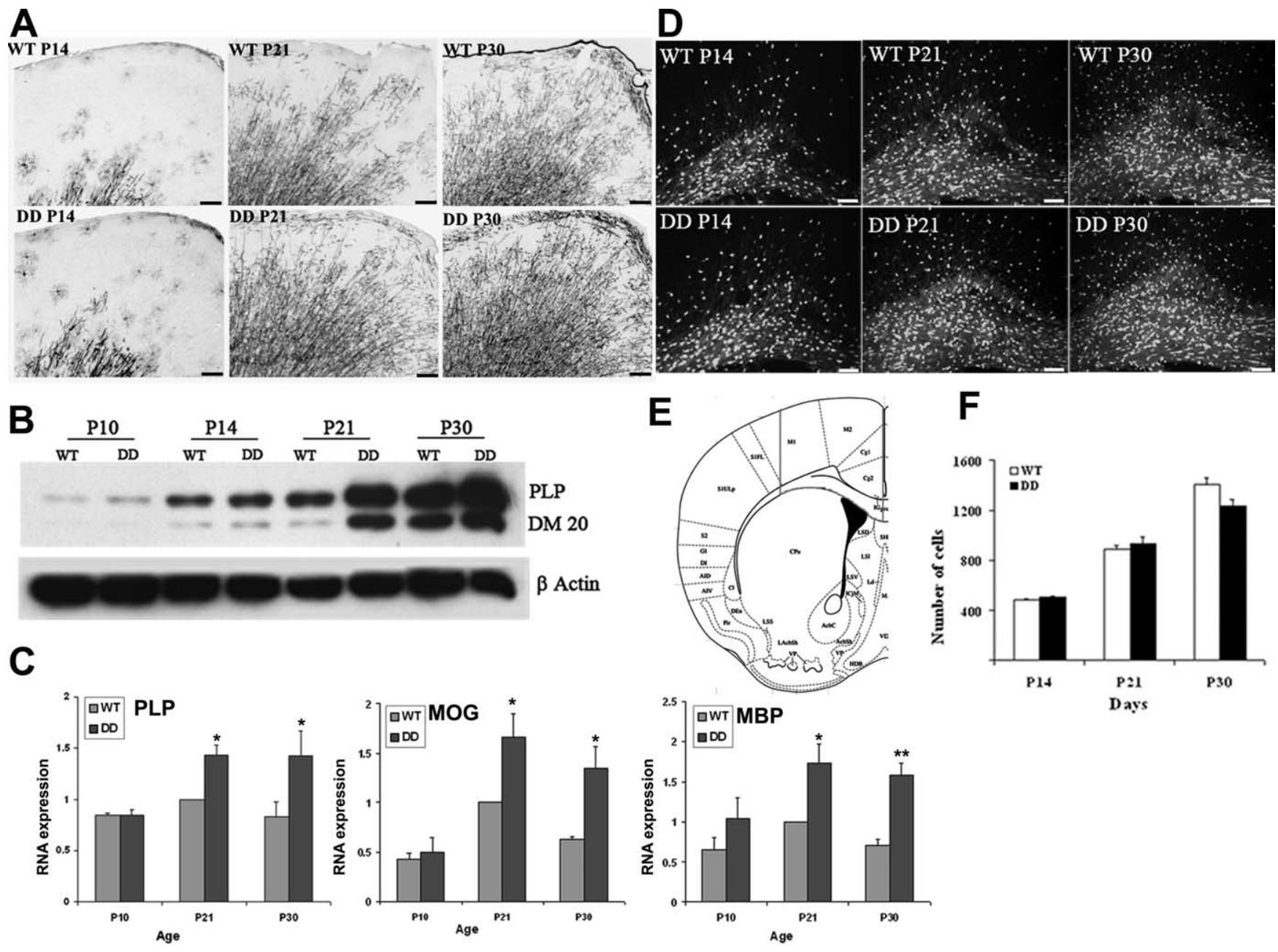

Figure 3. Myelination was early and enhanced in PIp-Akt-DD mice with no increase in oligodendrocyte cell number. A, Cerebrum samples from WT and PIp-Akt-DD9 littermates were immunostained for PLP/DM20 at P14, P21, and P30, and enhanced myelination was seen at all ages in Plp-Akt-DD9 compared with WT. Note increased premyelinating oligodendrocytes at P14 and increased myelinated areas at older ages. This image is representative of different experiments, in which between 3 and 10 pairs of animals were analyzed per age. Scale bars, $100 \mu \mathrm{m}$. $\boldsymbol{B}$, Samples were analyzed for PLP and DM20 by Western blot, at P10, P14, P21, and P30. This is a representative image of blots of between three and five pairs of animals per age. PLP/DM20 expression was increased as early as P10, compared with WT. C, RNA was prepared from cerebrum samples at P10, P21, and P30, and quantified for PLP, MOG, and MBP by real-time PCR. Samples were quantified, relative to a standard RNA, GAPDH, and expressed relative to WT samples at P21, which were given an arbitrary value of 1.0. Thus, changes in WT RNA levels were analyzed over time, along with differences between WT and transgenic samples. $n=3 .{ }^{*} p \leq 0.05 ;{ }^{* *} p<0.005$. D, To quantify the number of oligodendrocytes, the PIp-Akt-DD9 transgene was crossed into PIp-EGFP mice. Coronal sections were imaged for EGFP-expressing oligodendrocytes in cortical areas of WT/PIp-EGFP and Plp-Akt-DD9/PIp-EGFP littermates at P14, P21, and P30. Scale bars, $100 \mu \mathrm{m}$. E, The area of motor and cingulate cortex analyzed for quantifying oligodendrocytes in WT/PIp-EGFP and Plp-Akt-DD9/PIp-EGFP littermates is boxed [Franklin and Paxinos (2008), their Fig. 24, modified with permission]. It includes part of M1 (primary motor cortex), M2 (secondary motor cortex), Cg1 (cingulate cortex area 1), Cg2 (cingulate cortex area 2), and the associated subcortical white matter. $\boldsymbol{F}$, Quantification of oligodendrocytes at P14, P21, and P30, in the area outlined in $\boldsymbol{E}$, showed no difference in the number of oligodendrocytes between WT and PIp-Akt-DD9 mice at all ages studied. $n=3$ per age per genotype. Error bars represent SEM.

\section{Diffraction clearly distinguished Plp-Akt-DD mice as hypermyelinated}

The increase in CNS myelin with age was measured in optic nerve by $\mathrm{x}$-ray diffraction as well (Fig. 5D). X-ray diffraction measures myelin period and molecular interactions within myelin, and the proportion of the myelin diffraction compared with the total $\mathrm{x}$-ray scatter can be used to determine the relative amount of myelin (Avila et al., 2005). The $\mathrm{x}$-ray patterns showed stronger myelin diffraction from the Plp-Akt-DD mice compared with WT even at 2 months of age, i.e., increased by approximately one-third; and at 6 months of age, the x-ray scatter from the Plp-Akt-DD mice was substantially greater (nearly double). Between these ages, very little change in the relative amount of myelin was noted in WT optic nerve (Fig. 5D, open and closed circles). In neither line was there any change in the $\sim 156 \AA$ period (Fig. $5 D$, triangles). When analyzed by electron microscopy of optic nerve in older animals, this hypermyelination produced myelin that appeared uncompacted and inconsistently increased around some axons (Fig. 5E). Thus, for these samples, $\mathrm{x}$-ray diffraction was the ideal method for demonstrating the increases in CNS myelin as these animals aged. Using $\mathrm{x}$-ray diffraction with unfixed tissue eliminates the impact of the chemical treatments of the sample for electron microscopy, which apparently made it difficult to analyze the myelin in older Plp-Akt-DD mice. These experiments emphasize the advantage of $\mathrm{x}$-ray diffraction, not only for measuring myelin period, but for quantifying relative amounts of native myelin content in normal and pathological samples.

No increase in the number of oligodendrocytes was noted in older Plp-Akt-DD mice

Given the increase in the size of the white matter areas of the brain and the excess myelin generated in Plp-Akt-DD mice, it was im- 

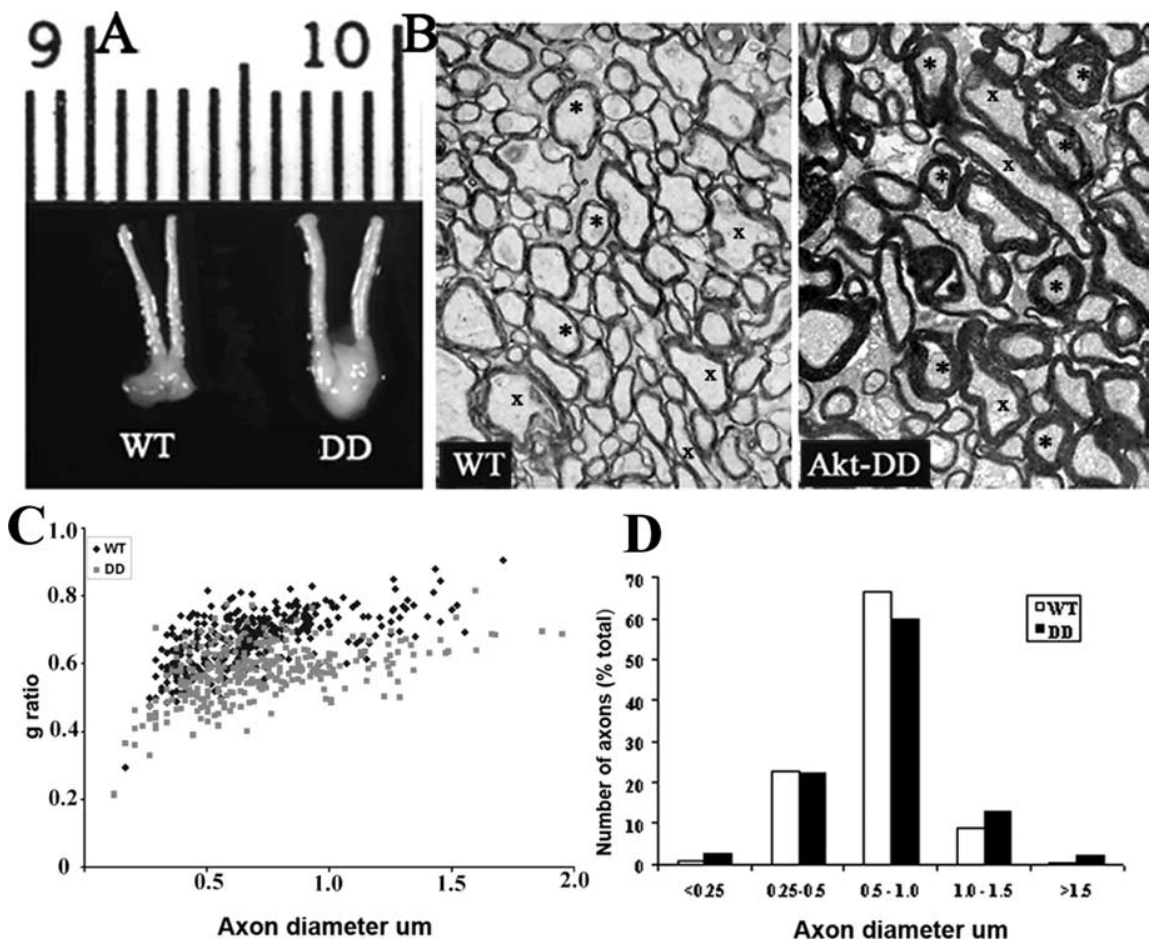

Figure 4. Optic nerves from PIp-Akt-DD mice were larger and had increased myelin, relative to WT mice. $A, 0$ ptic nerves from WT and PIp-Akt-DD9 mice at 2 months of age were imaged ( $n=15$ per genotype), and PIp-Akt-DD9 nerves were dramatically larger than WT. B, Electron micrographs of WT and PIp-Akt-DD9 optic nerves at 2 months of age. Relatively circular axons, such as those labeled with asterisks, were used for calculating $g$ ratio, whereas those with irregular shape, e.g., those labeled with $\mathrm{x}$, were excluded from the analysis. Three samples were analyzed per genotype, and representative images are shown. Magnification, $6300 \times$. C, Scatter diagram showing the distribution of the $g$ ratio as a function of axon diameter in WT and Plp-Akt-DD9 optic nerve at 2 months of age. $g$ ratios and axon diameters were plotted for individual axons. WT data points are in black; PIp-Akt-DD data points are in gray. D, Quantification of the number of axons in different size distribution for the two genotypes. Three pairs of optic nerves per genotype were used for calculation of $g$ ratio and axon diameter.

portant to assess whether as animals aged, there was an increase in the number of cells, which might have been subtle in younger animals but accumulate with age. $P l p$-Akt-DD/Plp-EGFP mice were compared with $\mathrm{WT} / \mathrm{Pl} p$-EGFP mice for the number of oligodendrocytes (Fig. 6). Because the corpus callosum in $\mathrm{Plp}$ Akt-DD mice was enlarged, we measured numbers of oligodendrocytes per cubic millimeter, and the total area of the corpus callosum in coronal sections at the same bregma coordinates from three mice/genotype (Fig. 6A,B). When quantified for WT and $P l p$-Akt-DD mice, there was a significant increase in the size of the corpus callosum in Plp-Akt-DD brain (Table 1). Very little variance of the corpus callosum area was seen within each genotype. Thus, the difference in area between genotypes was highly significant. As described in Table 1, the density of oligodendrocytes in the central corpus callosum [Fig. 6A, $B$ (yellow box), Fig. $6 C, D]$ was lower in $P l p$-Akt-DD mice compared with WT mice, but the difference was not statistically significant $(p=0.083 ; n=$ 3 ). The total number of oligodendrocytes quantified in the central corpus callosum (through $15 \mu \mathrm{m}$ of the section) was comparable between WT and Plp-Akt-DD mice. Additionally, the number of oligodendrocytes in the entire corpus callosum (analyzing only $1 \mu \mathrm{m}$ thickness) in the hemisphere was also derived by multiplying the density by the respective areas measured. In both cases, the total number of oligodendrocytes was comparable between WT and Plp-Akt-DD samples (Table 1). Stated briefly, the density of oligodendrocytes in the corpus callosum of $\mathrm{Plp}$ Akt-DD mice was reduced, relative to WT, consistent with the concept that there was excess myelin in the Plp-Akt-DD tissue.
However, when the total number of oligodendrocytes was quantified, either in the region of interest or in the total corpus callosum, there was no difference.

\section{Peripheral myelination was not impacted by overexpression of constitutively active Akt}

Despite its role in oligodendrocyte differentiation, Akt overexpression in sciatic nerve had no impact on myelination. The Plp gene is expressed in Schwann cells (Puckett et al., 1987), and our transgene promoter is expressed in both myelinating and nonmyelinating Schwann cells (Jiang et al., 2000; Wight et al., 2007). Expression of Akt in sciatic nerve was elevated in $P l p$ Akt-DD mice at 3 months of age (Fig. 7A). However, there was no increase in the amount of PLP, MBP (data not shown), or P0 protein (Fig. 7A; for data on Plp-AktDD5, see supplemental Fig. 5, available at www.jneurosci.org as supplemental material). Additionally, when sciatic nerves from 2- and 6-month-old animals were analyzed by x-ray diffraction, Akt expression had no impact on the amount of myelin (Fig. 7B). Consistent with earlier diffraction studies (Hedley-Whyte and Kirschner, 1976; Kirschner and Sidman, 1976), there was an increase in myelin of $\sim 10 \%$ from 2 to 6 months of age in both $P l p$ Akt-DD and WT sciatic nerves $(p<$ $0.0001)$, and an $\sim 1 \AA$ increase in myelin period was also observed $(p<0.0001$;

from 172.4 to $173.6 \AA$ ) (Fig. $7 B$ ). However, these increases occurred in both sets of nerves; i.e., there was no difference between WT and $P l p$-Akt-DD nerves at either age. The lack of impact of Akt in myelinating Schwann cells was confirmed with $1 \mu \mathrm{m}$ Epon sections, where ventral roots from both transgenic and WT mice were indistinguishable (Fig. 7C). Thus, the signaling controlling myelination in the peripheral nervous system (PNS) appeared to be regulated differently than that in oligodendrocytes, and not directly through Akt.

\section{Discussion}

The current studies were undertaken to investigate the role of Akt in enhancing oligodendrocyte and oligodendrocyte progenitor cell survival, because the PI3 kinase/Akt pathway mediates oligodendrocyte progenitor cell survival and proliferation, and survival of mature oligodendrocytes induced by numerous compounds (Canoll et al., 1999; Ebner et al., 2000; Flores et al., 2000; Ness and Wood, 2002; Baron et al., 2003; Jaillard et al., 2005; Cui et al., 2006; Pang et al., 2007). In most cases, growth factor and other signaling through PI3K and Akt has been shown to impact primarily cell proliferation and cell survival. For example, PDGFR $\alpha$ has been shown in many systems, including oligodendrocytes, to enhance survival by signaling through Akt (Franke et al., 1995; Baron et al., 2003), as has the muscarinic acetylcholine receptor (Cui et al., 2006). Far more information is available on the signaling of the IGF-1 receptor through Akt in oligodendrocytes. IGF-1 signaling through Akt enhances oligodendrocyte progenitor cell survival after glutamate exposure (Ness and 
$\mathbf{A}$
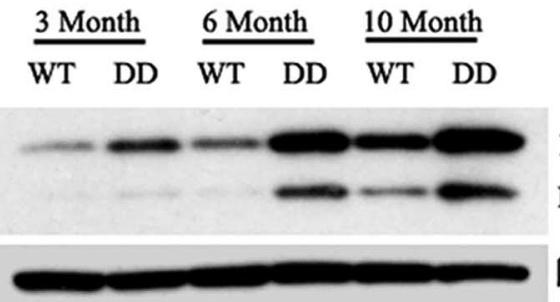

PLP

DM 20

$\beta$ Actin

$\mathbf{C}$

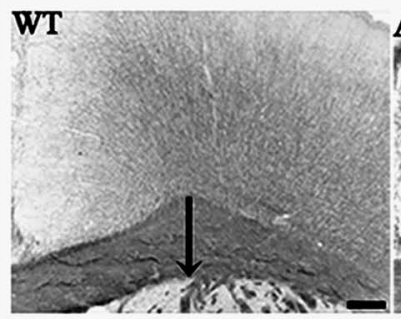

D

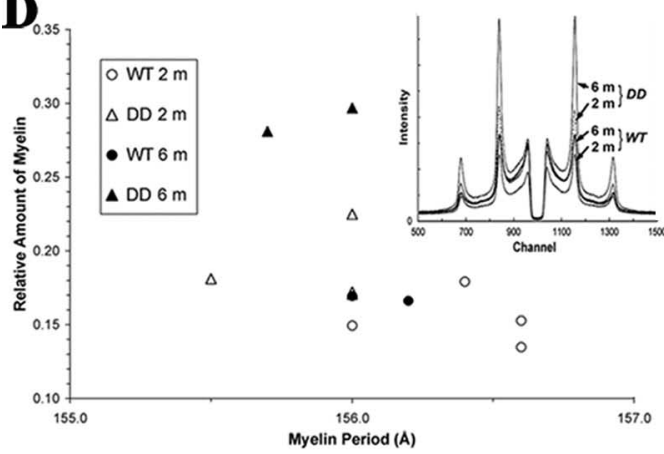

B
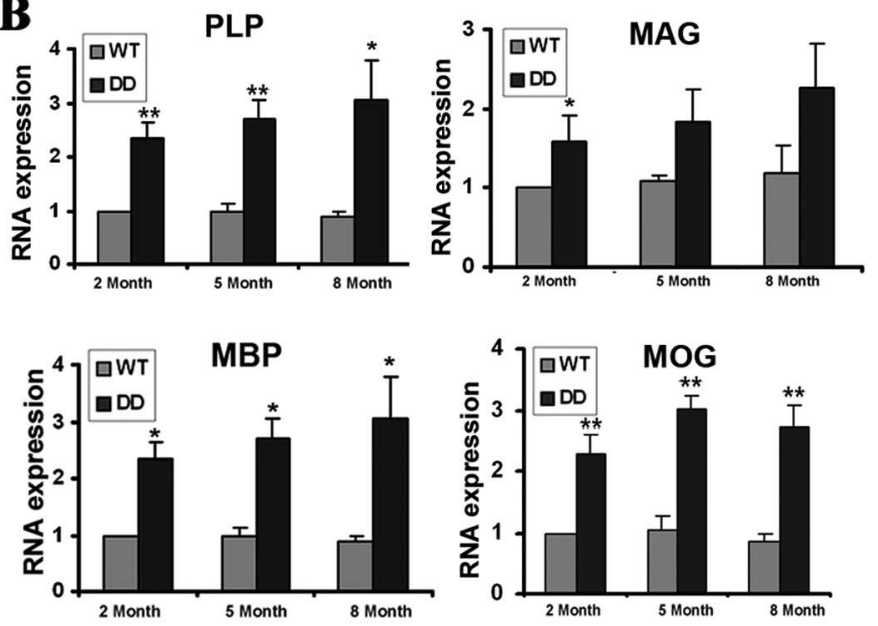

$\mathbf{E}$

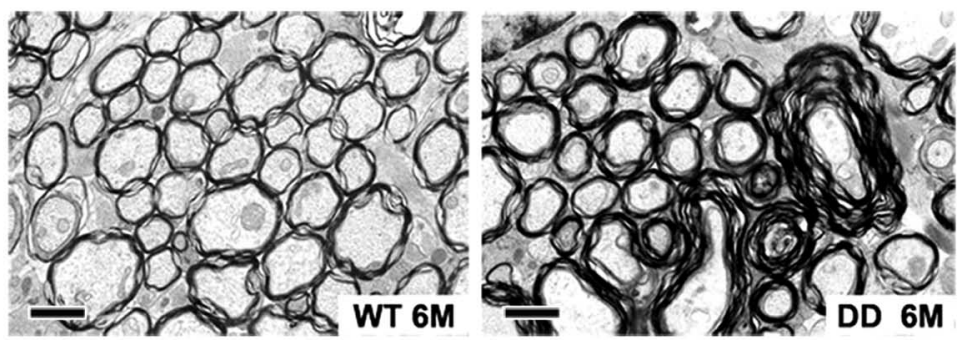

Figure 5. Enhanced myelination continued as PIp-Akt-DD mice aged. $A$, Cerebrum samples were analyzed for PLP/DM20 expression by Western blot at 3, 6, and 10 months of age $(n=3-5$ samples per age per genotype), and both were upregulated in PIp-Akt-DD9 at all ages. $B$, (erebrum samples were analyzed for PLP/DM20, MAG, MBP, and MOG mRNA expression by real-time PCR at 2,5, and 8 months of age, and all were upregulated in Plp-Akt-DD9 at all ages. Samples were quantified, relative to a standard RNA, GAPDH, and then expressed relative to WT samples at 2 months of age, which were given an arbitrary value of 1.0. Thus, changes in WT RNA levels with age are presented, as well as changes in transgenic RNA levels, relative to WT. $n=3 .{ }^{*} p \leq 0.05$; ${ }^{* *} p<0.005$. Error bars represent SEM. C, Tissue sections were analyzed for MBP expression by immunohistochemistry at 5 months of age, which was significantly increased. In addition, enlargement of the corpus callosum (arrows) was noted ( $n=16$ animals per genotype at 5-6 months of age). Scale bars, $200 \mu \mathrm{m}$. Representative images of the immunocytochemistry are shown. $\boldsymbol{D}$, WT (circles) and PIp-Akt-DD9 (triangles) samples were analyzed for myelin content by $x$-ray diffraction at 2 (open symbols) and 6 (closed symbols) months of age. At 2 months of age, four optic nerves were analyzed for WT mice and three for PIp-Akt-DD9 mice; at 6 months of age, two nerves each were analyzed. Individual data points are presented. Inset, Raw diffraction spectra used to obtain quantitative data of the relative amount of myelin. No data points are obscured beneath this inset. E, Electron micrographs of WT and PIp-Akt-DD9 optic nerves at 6 months of age. Magnification, 10,000 X. At least three samples were analyzed per genotype, and a representative image is shown.

Wood, 2002; Ness et al., 2002), growth factor deprivation (Cui et al., 2005), or psychosine exposure, as would be seen in globoid cell leukodystrophy (Zaka et al., 2005).

In addition to impacting oligodendrocyte progenitor cell survival, the PI3K/Akt pathway also regulates survival of mature oligodendrocytes. Edg8 (endothelial differentiation gene 8)/S1P5 (sphingosine 1 phosphate receptor 5) signaling enhances survival via Akt in mature oligodendrocytes, but not progenitors in a growth factor deprivation paradigm (Jaillard et al., 2005). In vivo, leukemia inhibitory factor (LIF) also acts via Akt to reduce oligodendrocyte apoptosis in a model of spinal cord injury (Azari et al., 2006). Thus, Akt acts downstream of many signaling systems to enhance oligodendrocyte and oligodendrocyte progenitor cell survival.

In addition to its survival effect, IFG-1 enhances oligodendrocyte progenitor cell proliferation, and Akt activity is required for this, although other signaling pathways, including MEK1/ERK, are activated downstream of Akt (Cui and Almazan, 2007). This regulation appears to function in part through increases in cyclin D1, which rises rapidly after induction of proliferation (Tang et al., 2001; Huang et al., 2002). Frederick et al. (2007) demonstrated that after IGF-1 induces Akt activity in oligodendrocyte progenitor cells, GSK-3 $\beta$ is phosphorylated and thereby inactivated. Because GSK- $3 \beta$ controls the subcellular localization and proteolytic degradation of cyclin D1 (Diehl et al., 1998), GSK-3 $\beta$ inactivation would be expected to reduce degradation of cyclin D1. Indeed, Frederick et al. (2007) demonstrated that IGF-1 increases cyclin D1 through inhibition of proteosome activity resulting from GSK-3 $\beta$ inactivation.

Given this body of data, it was quite striking that overexpression of constitutively active Akt in oligodendrocytes and their progenitor cells in vivo apparently had no impact on oligodendrocyte progenitor cell proliferation or survival, or on oligodendrocyte number during development or in older Plp-Akt-DD mice. It must be noted that these earlier studies demonstrating Akt survival signaling were generally in vitro analyses of oligodendrocyte/oligodendrocyte progenitor cells. Although no enhanced survival of oligodendrocytes or their progenitors was seen in $\mathrm{Plp}$ Akt-DD mice, Akt may still impact oligodendrocyte survival in vivo. Developmental cell loss may be regulated differently in vivo, relative to in vitro, and the basal Akt signaling pathways controlling oligodendrocyte cell number in vivo may be sufficient to establish the correct number of oligodendrocytes. Thus, increasing Akt activity in these cells may not be able to override that 

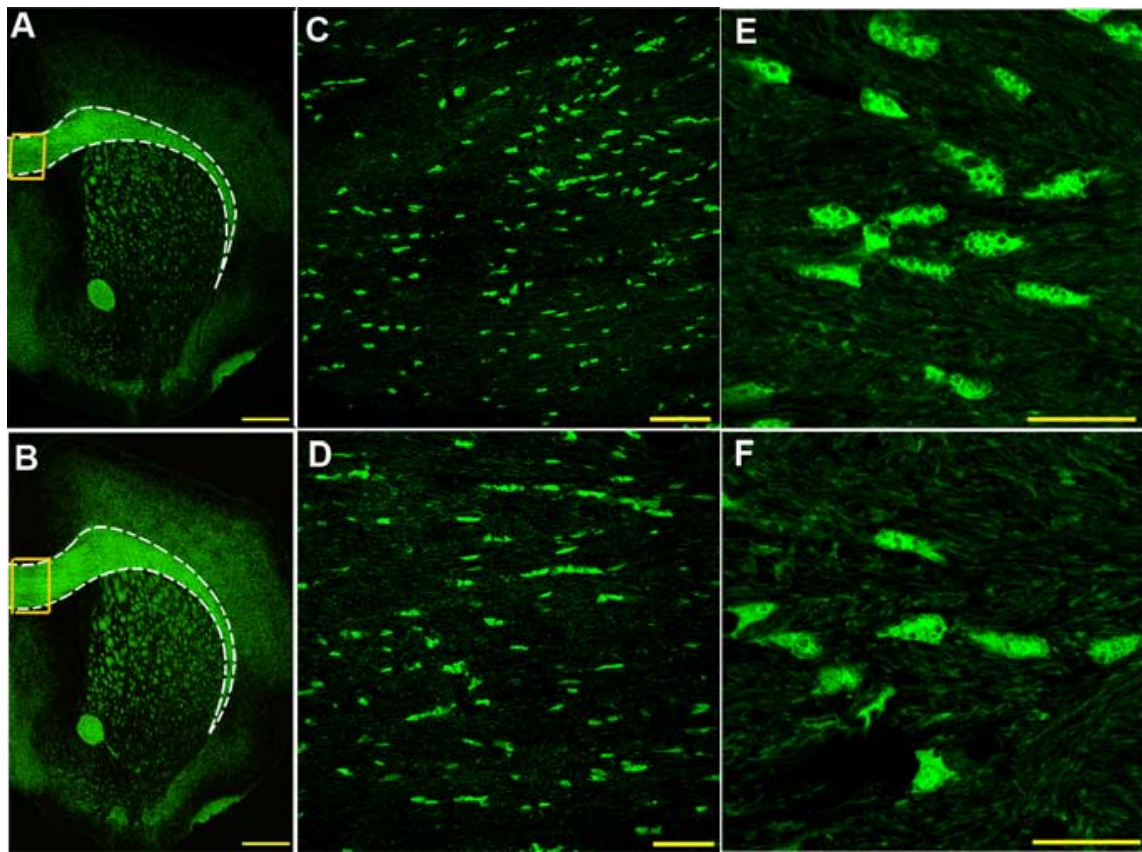

Figure 6. Enlarged area and reduced oligodendrocyte density in 6-month-old PIp-Akt-DD corpus callosum. $\boldsymbol{A}, \boldsymbol{B}$, Confocal images showing corpus callosum per hemisphere in WT and Plp-Akt-DD9 mice. The area occupied by corpus callosum in Plp-AktDD9 $(\boldsymbol{B})$ appeared larger than that in WT $(\boldsymbol{A})$. Scale bars, $500 \mu \mathrm{m} . \boldsymbol{C}, \boldsymbol{D}$, Representative confocal images taken at the central corpus callosum used for quantifying oligodendrocytes in WT (C) and PIp-Akt-DD9 (D) samples. Scale bars, $50 \mu \mathrm{m}$. $\boldsymbol{E}$, $\boldsymbol{F}$, Highermagnification images showing that the number of oligodendrocytes per field of view is more in WT $(\boldsymbol{E})$ than in PIp-Akt-DD9 (F) samples. Scale bars, $25 \mu \mathrm{m}$. Quantification of oligodendrocyte density (expressed as cells per cubic millimeter) at the central corpus callosum and the total number of oligodendrocytes in the corpus callosum are described in Table $1 . n=3$ per genotype.

Table 1. Quantification of oligodendrocytes in the corpus callosum

\begin{tabular}{lcc}
\hline & WT & Plp-Akt-DD \\
\hline C. area $\left(\mathrm{mm}^{2}\right)$ & $0.948 \pm 0.06$ & $1.363 \pm 0.05^{*}$ \\
OL density $\left(\right.$ cells $\left./ \mathrm{mm}^{3}\right)$ & $269.84 \pm 25.2 \times 10^{3}$ & $193.17 \pm 21.8 \times 10^{3}$ \\
Number of OLs quantified at central CC & $308.70 \pm 61.3$ & $286.46 \pm 87.2$ \\
Number of OLs calculated in entire CC & $16.89 \pm 1.1 \times 10^{3}$ & $17.72 \pm 1.3 \times 10^{3}$
\end{tabular}

Corpus callosum area was significantly greater in Plp-Akt-DD brain than WT (Fig. $6 A, B)\left(n=6\right.$ per genotype; $\left.{ }^{*} p<0.00005\right)$. Oligodendrocyte density (expressed as cells per cubic millimeter) at the central corpus callosum was quantified, and the cell density was lower in Plp-Akt-DD9 samples than in WT (Fig. $6 C, D)$. The total number of oligodendrocytes in the central corpus callosum (the area in the yellow boxes in Fig. $6 A, B$, which are of identical width and span the entire height of the corpus callosum) was quantified in $15 \mu \mathrm{m}$ sections from PIp-Akt-DD and WT brains, and there was no statistically significant difference ( $n=3$ per genotype). The total number of oligodendrocytes in the corpus callosum per hemisphere was derived by multiplying the area calculated for each section used by the respective density, and there was no statistically significant difference. This calculation was done for a thickness of $1 \mu \mathrm{m}$, because this was the most accurate representation of corpus callosum area, which was measured directly in a single $z$-stack image. These data demonstrated that the total number of oligodendrocytes in the corpus callosum remained the same in WT and Plp- Akt-DD9 samples. CC, Corpus callosum; OL, oligodendrocyte.

regulation. Alternatively, a separate signaling pathway may be the major determinant of oligodendrocyte cell number, and/or the Akt pathway may be involved in survival only in pathological conditions, such as in the spinal cord injury model with reduced oligodendrocyte apoptosis induced by LIF signaling through Akt (Azari et al., 2006).

Very few studies have focused on the impact of Akt signaling in oligodendrocyte differentiation. Palacios et al. (2005) suggested that whereas the induction of oligodendrocyte differentiation by IGF-1 requires both the mitogen-activated protein (MAP) kinase and PI3 kinase pathways, the transcription factor cAMP response element-binding protein (CREB) and CREBbinding protein, which regulate transcription of myelin genes, are specifically controlled by the MAP kinase pathways, and not through Akt. The differentiation of oligodendrocytes induced by NT3 or BDNF is also controlled by MAP kinase rather than Akt (Hu et al., 2004; Du et al., 2006). Thus, it is of some interest that overexpression of Akt in oligodendrocytes in vivo is primarily inducing increased myelination, rather than impacting survival or proliferation. Again, the possibility exists that because the studies on the lack of an impact of Akt on differentiation were typically done by testing only one inducer of differentiation in vitro, the more physiological inducer of differentiation was either not tested or does not have the same impact in vitro. Akt, in fact, does impact cell differentiation in certain cell systems. In several tissues, its overexpression induces hypertrophy and organ growth, because of hyperplasia (BernalMizrachi et al., 2001; Bodine et al., 2001; Matsui et al., 2002; Shioi et al., 2002). In the nervous system, Akt signaling regulates axon caliber and branching in sensory axons (Markus et al., 2002), and defines axons relative to dendrites in vitro (Jiang et al., 2005; Yoshimura et al., 2005). Our recent studies on BACE1 ${ }^{-/-}$mice show CNS hypomyelination and Akt inactivation $(\mathrm{Hu}$ et al., 2006), which is consistent with the current studies showing that Akt signaling can regulate the amount of myelin.

The hypermyelination in $P l p$-Akt-DD mice is quite different from that in $\mathrm{p} 27^{-1-}$ mice, which have cerebellar hypermyelination (Casaccia-Bonnefil et al., 1997). In p $27^{-1-}$ mice, the hypermyelination results from a reduction in the efficiency of cell cycle exit. Increased progenitor cell cycling generates increased numbers of myelinating cells, and thereby more myelin. In contrast, the $P l p$-Akt-DD mice had normal numbers of oligodendrocytes, but increased myelin per oligodendrocyte, which is similar to mice that overexpress IGF-1 (Carson et al., 1993). In IGF-1overexpressing mice, there is a dramatic increase in the amount of myelin per oligodendrocyte, but normal numbers of oligodendrocytes as a percentage of total cells. As noted above, because IGF-1 acts via Akt, it may well be that the signaling inducing increased myelination in those mice is via Akt.

Given the data on CNS myelination in these mice, it was quite unexpected that Akt overexpression in Schwann cells in $\mathrm{Plp}$ Akt-DD mice did not increase PNS myelination. Neuregulin overexpression on PNS axons signals through ErbB receptors on Schwann cells to regulate the amount of myelin and the type of axons that are myelinated (Michailov et al., 2004; Taveggia et al., 2005; Chen et al., 2006), and PI3 kinase signaling has been shown to mediate neuregulin-induced differentiation of cultured Schwann cells (Maurel and Salzer 2000, Ogata et al., 2004). As noted above, GSK- $3 \beta$ is negatively regulated by Akt phosphorylation, and Ogata et al. (2004) demonstrated that GSK-3 $\beta$ inactivation by Akt enhanced myelin gene expression in Schwann cells. In other studies, IGF-1 was shown to stimulate de novo fatty acid biosynthesis, an essential myelin function, in dorsal root ganglion/Schwann cell cocultures through activation of Akt, and that this could be downregulated by siRNA-mediated Akt depletion (Liang et al., 2007). Several possibilities may explain the 


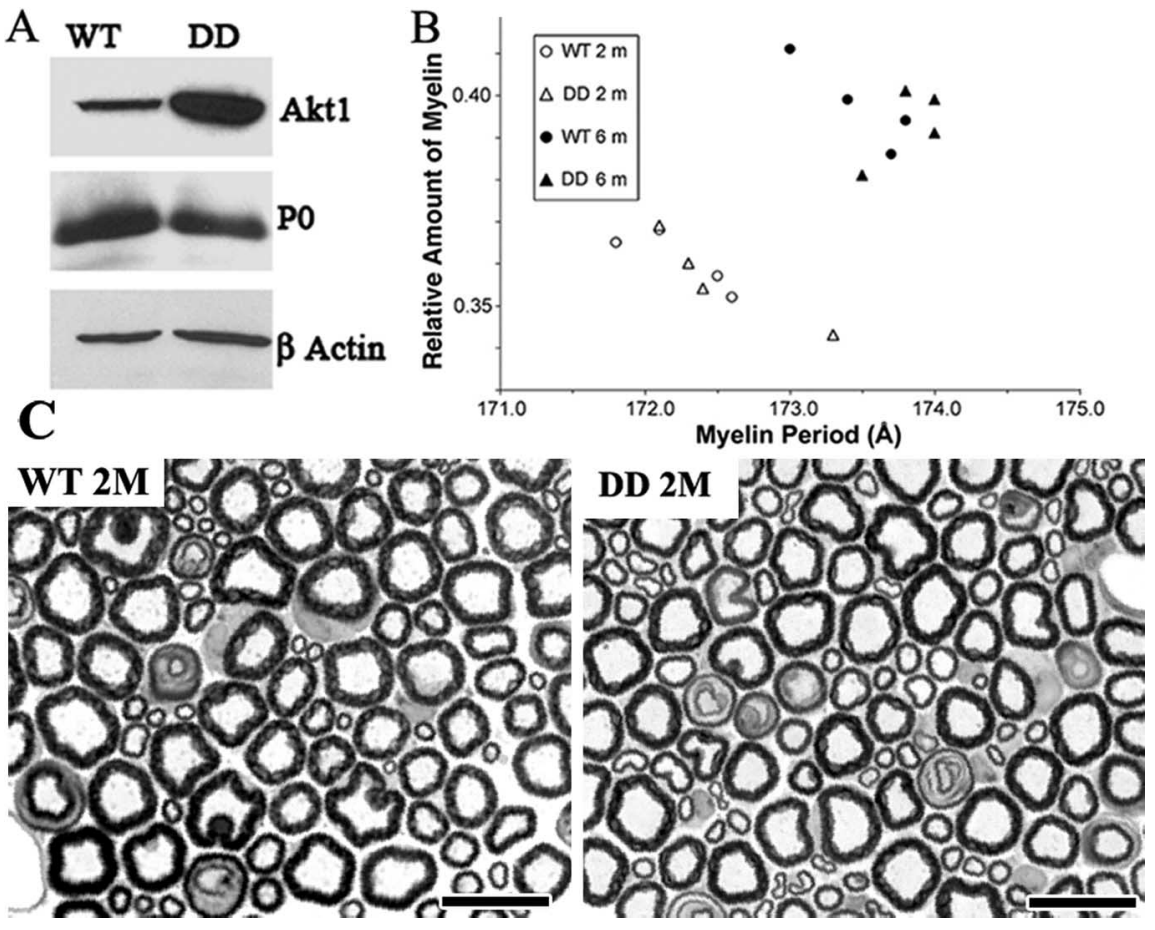

Figure 7. PNS myelination was not impacted by Akt-DD overexpression. $\boldsymbol{A}$, Sciatic nerves from WT and Plp-Akt-DD9 mice were analyzed for Akt (top), PO (middle), and actin (bottom) by Western blotting. Despite Akt overexpression in sciatic nerve, no increase in P0 was detected in Plp-Akt-DD9 mice. At least three samples were analyzed per age per genotype. $\boldsymbol{B}$, Sciatic nerves from WT (circles) and PIp-Akt-DD9 (triangles) were analyzed by x-ray diffraction and showed no difference in myelination. Four nerves from each genotype were analyzed at 2 (open symbols) or 6 (closed symbols) months of age. C, Epon sections (1 $\mu \mathrm{m}$ ) of WT and PIp-Akt-DD9 ventral roots at 2 months of age. Scale bars, $20 \mu \mathrm{m}$.

inability of constitutively active Akt to enhance myelination in sciatic nerve. One may simply be the dosage of Akt in Schwann cells, relative to oligodendrocytes, which may be too low to enhance PNS myelination. Thus, the relative increase in Akt in peripheral nerve may not be as great as in oligodendrocytes. Alternatively, basal PI3 kinase/Akt signaling may be sufficient to start Schwann cell differentiation, and, as with the survival function of Akt in oligodendrocytes in vivo, excess may be irrelevant. This would be consistent with studies by Maurel and Salzer (2000), who showed that PI3 kinase signaling is only required for initiation of Schwann cell differentiation. Another intriguing explanation would be that a crucial Akt-independent ErbB signaling intermediate between neuregulin/ErbB signaling in Schwann cells and control of PNS myelination is missing in the Plp-Akt-DD mice. Which of these possibilities mediates the differences between myelination in Schwann cells and oligodendrocytes and what Akt-independent signal may exist are important questions to address.

In summary, $P l p$-Akt-DD mice are an intriguing resource for investigations on the signaling events regulating myelination in both the CNS and the PNS. Both the signaling pathways regulating myelination and the transcriptional changes leading to continuing myelination can be analyzed. Some of the regulatory differences controlling CNS and PNS myelination may be identified using these mice. Clearly they will be valuable for investigating signaling that may enhance remyelination in human pathologies, where thinner myelin is a hallmark of remyelinated lesions.

\section{References}

Avila RL, Inouye H, Baek RC, Yin X, Trapp BD, Feltri ML, Wrabetz L, Kirschner DA (2005) Structure and stability of internodal myelin in mouse models of hereditary neuropathy. J Neuropathol Exp Neurol 64:976-990.
Azari MF, Profyris C, Karnezis T, Bernard CC, Small DH, Cheema SS, Ozturk E, Hatzinisiriou I, Petratos S (2006) Leukemia inhibitory factor arrests oligodendrocyte death and demyelination in spinal cord injury. J Neuropathol Exp Neurol 65:914-929.

Baron W, Decker L, Colognato H, ffrenchConstant C (2003) Regulation of integrin growth factor interactions in oligodendrocytes by lipid raft microdomains. Curr Biol 13: 151-155.

Bellacosa A, Testa JR, Staal SP, Tsichlis PN (1991) A retroviral oncogene, akt, encoding a serinethreonine kinase containing an SH2-like region. Science 254:274-277.

Bernal-Mizrachi E, Wen W, Stahlhut S, Welling CM, Permutt MA (2001) Islet beta cell expression of constitutively active Akt1/PKB alpha induces striking hypertrophy, hyperplasia, and hyperinsulinemia. J Clin Invest 108:1631-1638.

Bodine SC, Stitt TN, Gonzalez M, Kline WO, Stover GL, Bauerlein R, Zlotchenko E, Scrimgeour A, Lawrence JC, Glass DJ, Yancopoulos GD (2001) Akt/mTOR pathway is a crucial regulator of skeletal muscle hypertrophy and can prevent muscle atrophy in vivo. Nat Cell Biol 3:1014-1019.

Canoll PD, Kraemer R, Teng KK, Marchionni MA, Salzer JL (1999) GGF/neuregulin induces a phenotypic reversion of oligodendrocytes. Mol Cell Neurosci 13:79-94.

Carson MJ, Behringer RR, Brinster RL, McMorris FA (1993) Insulin-like growth factor I increases brain growth and central nervous system myelination in transgenic mice. Neuron 10:729-740.

Casaccia-Bonnefil P, Tikoo R, Kiyokawa H, Friedrich V Jr, Chao MV, Koff A (1997) Oligodendrocyte precursor differentiation is perturbed in the absence of the cyclin-dependent kinase inhibitor p27Kip1. Genes Dev 11:2335-2346.

Chen S, Velardez MO, Warot X, Yu ZX, Miller SJ, Cros D, Corfas G (2006) Neuregulin 1-erbB signaling is necessary for normal myelination and sensory function. J Neurosci 26:3079-3086.

Coggeshall RE (1992) A consideration of neural counting methods. Trends Neurosci 15:9-13.

Cui QL, Almazan G (2007) IGF-I-induced oligodendrocyte progenitor proliferation requires PI3K/Akt, MEK/ERK, and Src-like tyrosine kinases. J Neurochem 100:1480-1493.

Cui QL, Zheng WH, Quirion R, Almazan G (2005) Inhibition of Src-like kinases reveals Akt-dependent and -independent pathways in insulin-like growth factor I-mediated oligodendrocyte progenitor survival. J Biol Chem 280:8918-8928.

Cui QL, Fogle E, Almazan G (2006) Muscarinic acetylcholine receptors mediate oligodendrocyte progenitor survival through Src-like tyrosine kinases and PI3K/Akt pathways. Neurochem Int 48:383-393.

Diehl JA, Cheng M, Roussel MF, Sherr CJ (1998) Glycogen synthase kinase3beta regulates cyclin D1 proteolysis and subcellular localization. Genes Dev 12:3499-3511.

Du Y, Lercher LD, Zhou R, Dreyfus CF (2006) Mitogen-activated protein kinase pathway mediates effects of brain-derived neurotrophic factor on differentiation of basal forebrain oligodendrocytes. J Neurosci Res 84:1692-1702.

Ebner S, Dunbar M, McKinnon RD (2000) Distinct roles for PI3K in proliferation and survival of oligodendrocyte progenitor cells. J Neurosci Res 62:336-345.

Flores AI, Mallon BS, Matsui T, Ogawa W, Rosenzweig A, Okamoto T, Macklin WB (2000) Akt-mediated survival of oligodendrocytes induced by neuregulins. J Neurosci 20:7622-7630.

Franke TF, Yang SI, Chan TO, Datta K, Kazlauskas A, Morrison DK, Kaplan DR, Tsichlis PN (1995) The protein kinase encoded by the Akt proto- 
oncogene is a target of the PDGF-activated phosphatidylinositol 3-kinase. Cell 81:727-736.

Franklin KBJ, Paxinos G (2008) The mouse brain in stereotaxic coordinates, Ed 3. New York: Academic.

Frederick TJ, Min J, Altieri SC, Mitchell NE, Wood TL (2007) Synergistic induction of cyclin D1 in oligodendrocyte progenitor cells by IGF-1 and FGF-2 requires differential stimulation of multiple signaling pathways. Glia 55:1011-1022.

Frohman EM, Racke MK, Raine CS (2006) Multiple sclerosis-the plaque and its pathogenesis. N Engl J Med 354:942-955.

Fuss B, Mallon B, Phan T, Ohlemeyer C, Kirchhoff F, Nishiyama A, Macklin WB (2000) Purification and analysis of in vivo-differentiated oligodendrocytes expressing the green fluorescent protein. Dev Biol 218:259-274.

Hedley-Whyte ET, Kirschner DA (1976) Morphological evidence of alteration in myelin structure with maturation. Brain Res 113:487-497.

Hu X, Jin L, Feng L (2004) Erk1/2 but not PI3K pathway is required for neurotrophin 3-induced oligodendrocyte differentiation of post-natal neural stem cells. J Neurochem 90:1339-1347.

Hu X, Hicks CW, He W, Wong P, Macklin WB, Trapp BD, Yan R (2006) Bace1 modulates myelination in the central and peripheral nervous system. Nat Neurosci 9:1520-1525.

Huang Z, Tang XM, Cambi F (2002) Down-regulation of the retinoblastoma protein $(\mathrm{rb})$ is associated with rat oligodendrocyte differentiation. Mol Cell Neurosci 19:250-262.

Hutchinson J, Jin J, Cardiff RD, Woodgett JR, Muller WJ (2001) Activation of Akt (protein kinase B) in mammary epithelium provides a critical cell survival signal required for tumor progression. Mol Cell Biol 21:2203-2212.

Inouye H, Karthigasan J, Kirschner DA (1989) Membrane structure in isolated and intact myelins. Biophys J 56:129-137.

Jaillard C, Harrison S, Stankoff B, Aigrot MS, Calver AR, Duddy G, Walsh FS, Pangalos MN, Arimura N, Kaibuchi K, Zalc B, Lubetzki C (2005) Edg8/ S1P5: an oligodendroglial receptor with dual function on process retraction and cell survival. J Neurosci 25:1459-1469.

Jiang H, Duchala CS, Awatramani R, Shumas S, Carlock L, Kamholz J, Garbern J, Scherer SS, Shy ME, Macklin WB (2000) Proteolipid protein mRNA stability is regulated by axonal contact in the rodent peripheral nervous system. J Neurobiol 44:7-19.

Jiang H, Guo W, Liang X, Rao Y (2005) Both the establishment and the maintenance of neuronal polarity require active mechanisms: critical roles of GSK-3beta and its upstream regulators. Cell 120:123-135.

Kirschner DA, Sidman RL (1976) X-ray diffraction study of myelin structure in immature and mutant mice. Biochim Biophys Acta 448:73-87.

Liang G, Cline GW, Macica CM (2007) IGF-1 stimulates de novo fatty acid biosynthesis by Schwann cells during myelination. Glia 55:632-641.

Mallon BS, Shick HE, Kidd GJ, Macklin WB (2002) Proteolipid promoter activity distinguishes two populations of NG2-positive cells throughout neonatal cortical development. J Neurosci 22:876-885.

Markus A, Zhong J, Snider WD (2002) Raf and akt mediate distinct aspects of sensory axon growth. Neuron 35:65-76.

Matsui T, Li L, Wu JC, Cook SA, Nagoshi T, Picard MH, Liao R, Rosenzweig A (2002) Phenotypic spectrum caused by transgenic overexpression of activated Akt in the heart. J Biol Chem 277:22896-22901.

Maurel P, Salzer JL (2000) Axonal regulation of Schwann cell proliferation and survival and the initial events of myelination requires PI 3-kinase activity. J Neurosci 20:4635-4645.

Michailov GV, Sereda MW, Brinkmann BG, Fischer TM, Haug B, Birchmeier
C, Role L, Lai C, Schwab MH, Nave KA (2004) Axonal neuregulin-1 regulates myelin sheath thickness. Science 304:700-703.

Ness JK, Wood TL (2002) Insulin-like growth factor I, but not neurotrophin-3, sustains Akt activation and provides long-term protection of immature oligodendrocytes from glutamate-mediated apoptosis. Mol Cell Neurosci 20:476-488.

Ness JK, Mitchell NE, Wood TL (2002) IGF-I and NT-3 signaling pathways in developing oligodendrocytes: differential regulation and activation of receptors and the downstream effector Akt. Dev Neurosci 24:437-445.

Ogata T, Iijima S, Hoshikawa S, Miura T, Yamamoto S, Oda H, Nakamura K, Tanaka S (2004) Opposing extracellular signal-regulated kinase and Akt pathways control Schwann cell myelination. J Neurosci 24:6724-6732.

Palacios N, Sánchez-Franco F, Fernández M, Sánchez I, Cacicedo L (2005) Intracellular events mediating insulin-like growth factor I-induced oligodendrocyte development: modulation by cyclic AMP. J Neurochem 5:1091-1107.

Pang Y, Zheng B, Fan LW, Rhodes PG, Cai Z (2007) IGF-1 protects oligodendrocyte progenitors against TNFalpha-induced damage by activation of PI3K/Akt and interruption of the mitochondrial apoptotic pathway. Glia 55:1099-1107.

Peters A, Sethares C, Killiany RJ (2001) Effects of age on the thickness of myelin sheaths in monkey primary visual cortex. J Comp Neurol 435:241-248.

Puckett C, Hudson L, Ono K, Friedrich V, Benecke J, Dubois-Dalcq M, Lazzarini RA (1987) Myelin-specific proteolipid protein is expressed in myelinating Schwann cells but is not incorporated into myelin sheaths. J Neurosci Res 18:511-518.

Shioi T, McMullen JR, Kang PM, Douglas PS, Obata T, Franke TF, Cantley LC, Izumo S (2002) Akt/protein kinase B promotes organ growth in transgenic mice. Mol Cell Biol 22:2799-2809.

Tang DG, Tokumoto YM, Apperly JA, Lloyd AC, Raff MC (2001) Lack of replicative senescence in cultured rat oligodendrocyte precursor cells. Science 291:868-871.

Taveggia C, Zanazzi G, Petrylak A, Yano H, Rosenbluth J, Einheber S, Xu X, Esper RM, Loeb JA, Shrager P, Chao MV, Falls DL, Role L, Salzer JL (2005) Neuregulin-1 type III determines the ensheathment fate of axons. Neuron 47:681-694.

Trapp BD, Nishiyama A, Cheng D, Macklin W (1997) Differentiation and death of premyelinating oligodendrocytes in developing rodent brain. J Cell Biol 137:459-468.

Wight PA, Duchala CS, Readhead C, Macklin WB (1993) A myelin proteolipid protein-LacZ fusion protein is developmentally regulated and targeted to the myelin membrane in transgenic mice. J Cell Biol 123:443-454.

Wight PA, Duchala CS, Shick HE, Gudz TI, Macklin WB (2007) Expression of a myelin proteolipid protein (Plp)-lacZ transgene is reduced in both the CNS and PNS of Plp (jp) mice. Neurochem Res 32:343-351.

Yates MA, Juraska JM (2007) Increases in size and myelination of the rat corpus callosum during adulthood are maintained into old age. Brain Res 1142:13-18.

Yoshimura T, Kawano Y, Arimura N, Kawabata S, Kikuchi A, Kaibuchi K (2005) GSK-3beta regulates phosphorylation of CRMP-2 and neuronal polarity. Cell 120:137-149.

Zaka M, Rafi MA, Rao HZ, Luzi P, Wenger DA (2005) Insulin-like growth factor-1 provides protection against psychosine-induced apoptosis in cultured mouse oligodendrocyte progenitor cells using primarily the PI3K/ Akt pathway. Mol Cell Neurosci 30:398-407. 